\title{
Deutsche Texte
}

Herausgegeben von

GotThart WUNBERG 



\section{Lyrik der Gründerzeit}

Ausgewählt, eingeleitet und herausgegeben von

GÜNTHER MAHAL

Max Niemeyer Verlag Tübingen 


\section{ISBN 3-484-19025-6}

(c) Max Niemeyer Verlag Tübingen 1973

Satz und Druck: Bücherdruck Wenzlaff, Kempten

Alle Rechte vorbehalten. Ohne ausdrüickliche Genehmigung des Verlages ist es auch nicht gestattet, dieses Buch oder Teile daraus auf photomechanischem Wege zu vervielfältigen. Printed Germany. 